Boise State University

ScholarWorks

Civil Engineering Faculty Publications and

Presentations

2020

\title{
Application of Bio-Stimulated Calcite Precipitation to Stabilize Expansive Soils: Field Trials
}

Bhaskar C.S. Chittoori

Boise State University

Anish Pathak

Boise State University

Malcolm Burbank

CDM Smith

Md Touhidul Islam

Gannett Fleming, Inc. 


\title{
Application of Bio-Stimulated Calcite Precipitation to Stabilize Expansive Soils: Field Trials
}

\author{
Bhaskar C.S. Chittoori \\ Assistant Professor \\ Dept. of Civil Engineering \\ Boise State University \\ Boise, ID \\ bhaskarchittoori@boisestate.edu \\ Anish Pathak \\ Graduate Student \\ Dept. of Civil Engineering \\ Boise State University \\ Boise, ID \\ anishpathak@u.boisestate.edu
}

\author{
Malcolm Burbank \\ Environmental Microbiologist \\ CDM Smith \\ Kellogg, ID \\ burbankm@cdmsmith.com
}

\author{
Md. Touhidul Islam \\ Geotechnical Designer \\ Gannett Fleming, Inc. \\ Marlton, NJ \\ tislam@gfnet.com
}

\begin{abstract}
This paper presents the results of a field implementation of microbial induced calcite precipitation to stabilize expansive soils in Marsing, Idaho. The field test was done by drilling 2.5 " $(6.35 \mathrm{~cm})$ diameter holes at a spacing of 16 " to 30 " $(40.6 \mathrm{~cm}$ to $76.2 \mathrm{~cm})$ into the ground and, injecting bio-enrichment followed by bio-cementation solutions to stimulate the native bacteria and subsequently achieve calcite precipitation. The $\mathrm{pH}$ level of the soil, the calcite content and free swelling potential were monitored over time by collecting periodic soil samples from the injection points. An increase in $\mathrm{pH}$ from 8.3 to 9.7 was seen in the first seven days after the injection of bio-enrichment solution. The calcite content in the soil increased and the free swelling potential decreased consistently with each subsequent injection of bio-cementation solution. The calcite content increased from $3 \%$ to $8 \%$ and the free swell index dropped from $114 \%$ to $29 \%$. The results show that microbial induced calcite precipitation can be successfully replicated in the field for the stabilization of expansive soils.
\end{abstract}

\section{Introduction}

Expansive soils undergo significant changes in volume with changing water content. These soils are widespread and annually cause billions of dollars in damages to various infrastructures around the world (Jones Jr \& Holtz, 1973). Various ground improvement techniques like chemical stabilization using lime or cement, deep soil mixing and moisture barriers are employed to counteract the problems due to these soils. However, engineers have observed subgrade failure even after lime and cement stabilization, attributed to: (a) stabilizer loss over time, or (b) certain physicochemical soil properties that render the stabilizer ineffective (other soils with similar index properties may respond well to the same stabilizer). Further, these chemical stabilizers have an adverse effect on the environment and economy. UNEP (2010) concluded that annually, around 7-8\% of overall $\mathrm{CO}_{2}$ emissions result from cement production alone. It is evident that there is a distinct need to develop sustainable and eco-friendly solutions to mitigate the problems with expansive soils.

Researchers have investigated innovative alternative foundation techniques such as drilled and belled piers, granular pile-anchors (Phanikumar, et. al, 2004; Rao et. al, 2004), and sand cushion technique for counteracting expansive soil problems. However, these methods can be very expensive - especially for constructing lightly loaded structures like pavements. Hence, it is important to identify both environmentally friendly and cost-effective methods. Using indigenous bacteria to stabilize expansive soils falls into this category. Bacteria are a dominant soil inhabitant with $\sim 10^{6}-10^{12}$ bacterial cells per gram of soil and containing as many as $10^{4}$ different genotypes (Torsvik, Goksoyr, \& Daae, 1990). Microbial metabolic activities often contribute to selective cementation by producing relatively insoluble organic and inorganic compounds both within and outside the cellular structure (Stocks-Fisher, Galinat, \& Bang, 1999). Microbial Induced Calcite Precipitation (MICP) is one such technique where the metabolic activity of certain 
This is an author-produced, peer-reviewed version of this conference proceeding. The final, definitive version of this document can be found online at Geo-Congress 2020, published by the American Society of Civil Engineers. Copyright restrictions may apply. doi: $10.1061 / 9780784482834.013$

types of bacteria present in the soil (Sporosarcina pasteurii) results in the formation of inorganic compounds (such as $\mathrm{CaCO}_{3}$ ) outside the cellular structure; these compounds can bind soil particles together. In MICP, one mole of urea, $\left(\mathrm{NH}_{2}\right)_{2} \mathrm{CO}$, is hydrolyzed into two moles of $\mathrm{NH}_{4}{ }^{+}$and one mole of $\mathrm{CO}_{3}{ }^{2-}$ by the microbial enzyme urease: $\mathrm{CO}\left(\mathrm{NH}_{2}\right)_{2}$ $+2 \mathrm{H}_{2} \mathrm{O} \rightarrow 2 \mathrm{NH}_{4}{ }^{+}+\mathrm{CO}_{3}{ }^{2-}$. In the presence of calcium ions, $\mathrm{CO}_{3}{ }^{2-}$ spontaneously precipitates as calcium carbonate: $\mathrm{Ca}^{2+}+\mathrm{CO}_{3}{ }^{2-} \rightarrow \mathrm{CaCO}_{3} . \mathrm{NH}_{4}{ }^{+}$generation increases local $\mathrm{pH}$ ( 9.5), and importantly further increases the rate of calcium carbonate precipitation. Researchers have demonstrated the MICP method by combining the ureolytic bacterium, Sporosarcina pasteurii (bio-augmentation), urea, and a source of calcium ions in laboratory and in the field (Whiffin, et. al, 2007; van Paassen, Whiffin, \& Harkes, 2007; van Paassen, et. al, 2010; van Paassen, 2011). Burbank, et al. (2013) demonstrated that biomineralized soils showed properties indicating that calcite precipitation increased soil resistance to seismic-induced liquefaction.

Researchers have shown that MICP was able to mitigate seismic-induced liquefaction, reduce permeability and compressibility, and increase shear strength (Whiffin, et. al, 2007; DeJong, et. al, 2006; Burbank M. B., et. al, 2011; van Paasen, 2009; Martinez, et al., 2013; Al Qabany \& Soga, 2013). There are two application strategies for this technology; bioaugmentation and biostimulation. Bioaugmentation is a process where urease-producing exogenous bacteria are added to the soil, whereas biostimulation uses indigenous bacteria already present in the soil to precipitate calcite.

Burbank et al. (2013) demonstrated that it was possible to stimulate indigenous microorganisms (bio-stimulation) to precipitate calcite. This method can be applied in situ without the need for reconstruction which involve excavation and mixing. This solution meets or lowers the costs of expansive soil stabilization and can be easily applied to soil with existing construction equipment used for treating expansive soils. By simply injecting the treatment solutions to the required depth we will avoid costly reconstruction using chemically stabilized subgrades or other design alternatives used to stabilize expansive soils.

This paper covers the results of an attempt to improve behavior of expansive soils using MICP in the field. The field test was carried out along the US 95 highway in Marsing, Idaho - 45 miles west of Boise, Idaho. This soil was classified as CH (High Plastic Clay) according to the Unified Soil Classification System (USCS). Atterberg's limit tests on the soil showed a liquid limit of 111 and plasticity index of 71 while the natural moisture content ranged between 36 to $38 \%$.

The field implementation method carried out in this study involves pressurized injection of a bio-enrichment solution and a bio-cementation solution into the ground at various time intervals to induce calcite precipitation. The injections were made in 2.5” $(6.35 \mathrm{~cm})$ diameter holes drilled up to a depth of 30" $(76.2 \mathrm{~cm})$. Bio-enrichment solution, consisting of urea, sodium acetate anhydrous and solulys, was injected to stimulate the growth of bacteria in the soil. Subsequently, multiple bio-cementation solutions were injected at various intervals to facilitate the precipitation of calcite. Soil samples taken from injection points were tested after each round of injection and the change in calcite content was observed.

\section{Equipment Setup}

The equipment used in field test included - handheld power auger (to drill borehole), Pneumatic packer system (to seal the borehole), water tank or reservoir (to hold treatment solutions), hydraulic pump (to inject treatment solutions under pressure), soil core (to collect samples from different depths). A portable gas-powered earth auger was used to drill injection points in the field site (Figure 1-a). A spiral auger head 2.5” (6.35 cm) in diameter was used to drill holes up to a depth of 30" $(76.2 \mathrm{~cm}$ ) into the ground. A 25-gallon (94.6 liters) solution tank (Figure 1-b) was connected to a portable water pump (Figure 1-d) to feed the injection solution. The water pump could be operated in the field by connecting it to a $12 \mathrm{~V}$ car battery. The water pump had a rated capacity to pump 5.5 gallons (20.8 liters) per minute (20 liters per minute) at a pressure of $60 \mathrm{psi}(413.7 \mathrm{kPa})$. A paddle mixer was used to mix the solutions in the tank (Figure 1-e). The outlet from the portable water pump was connected to a pneumatic packer that injected the solution into the ground (Figure 1-c). A single point pneumatic packer was used for this project. The packer can be inflated with air through a 1/8” (3.2 mm) outer diameter tubing that extends from the packer to the ground surface. A manual hand pump with a gauge can be used to inflate the packer. The outer diameter of the packer used for this project was 1.8 " $(4.6 \mathrm{~cm})$ when uninflated. On the surface, the inlet of the packer (Figure 1-c. i) is connected to the outlet from the water pump. At the outlet of the packer (Figure 1-c. ii), a PVC Tee connection was attached such that the solution would be pushed out laterally from the tube. A pressure gauge at the inlet of the packer was used to read the pressure within the injection tube. 
This is an author-produced, peer-reviewed version of this conference proceeding. The final, definitive version of this document can be found online at Geo-Congress 2020, published by the American Society of Civil Engineers. Copyright restrictions may apply. doi: $10.1061 / 9780784482834.013$

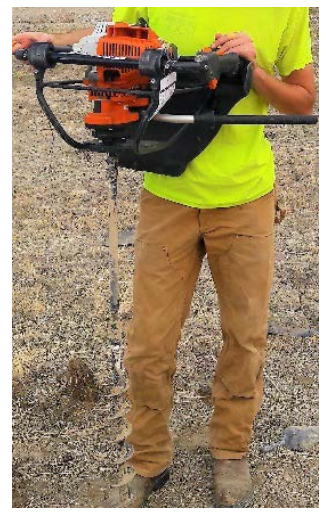

(a)

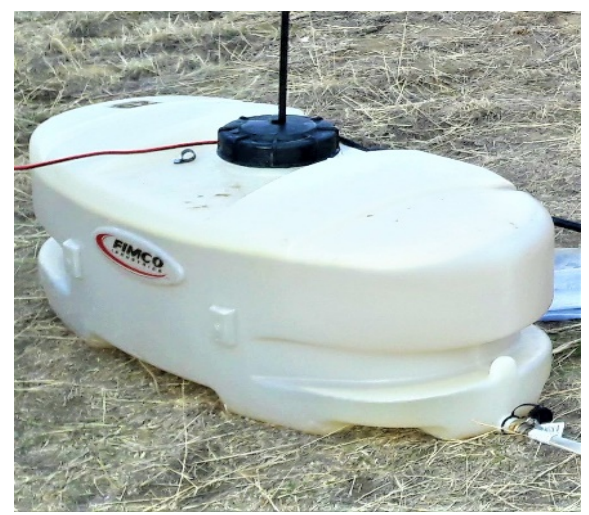

(b)

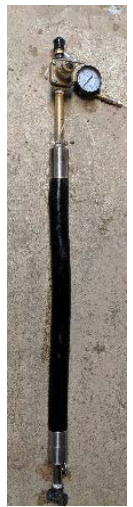

(c)

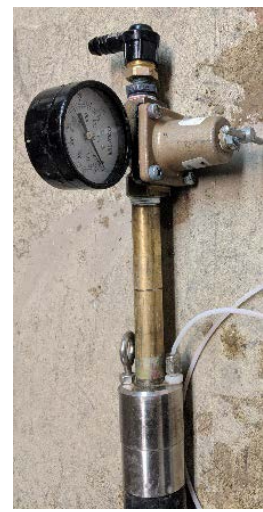

(c.1)

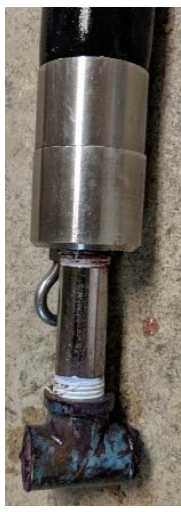

(c.2)

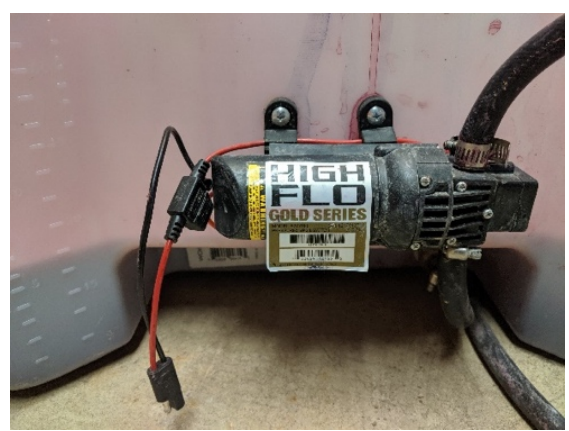

(d)

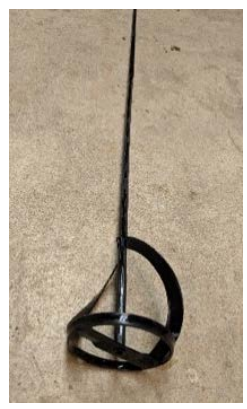

(e)

Figure 1 Photographs of equipment (a) Handheld power auger (b) 25-gallon Tote tank (c) Pneumatic packer (c.1) Packer outlet (c.2) Packer inlet (d) Water pump (e) Paddle mixer

\section{Injection Method}

The chemicals were injected into the ground through seven injection points that were spread apart at fixed distances to form two interlocking grids. The first grid consisted of four holes spaced 16" $(40.6 \mathrm{~cm})$ on center and the second grid consisted of four holes spaced at 30" x 20" $(76.2 \mathrm{~cm}$ x $50.8 \mathrm{~cm}$ ) (see Figure 2). The injected solutions consisted of two separate mixes for enrichment and cementation shown in Table 1. The chemicals were purchased in powder form and mixed on site in the tote tank (reservoir) using a paddle mixer. The tank was thoroughly cleaned between injections to ensure no calcite buildup inside the tank. 
This is an author-produced, peer-reviewed version of this conference proceeding. The final, definitive version of this document can be found online at Geo-Congress 2020, published by the American Society of Civil Engineers. Copyright restrictions may apply. doi: $10.1061 / 9780784482834.013$

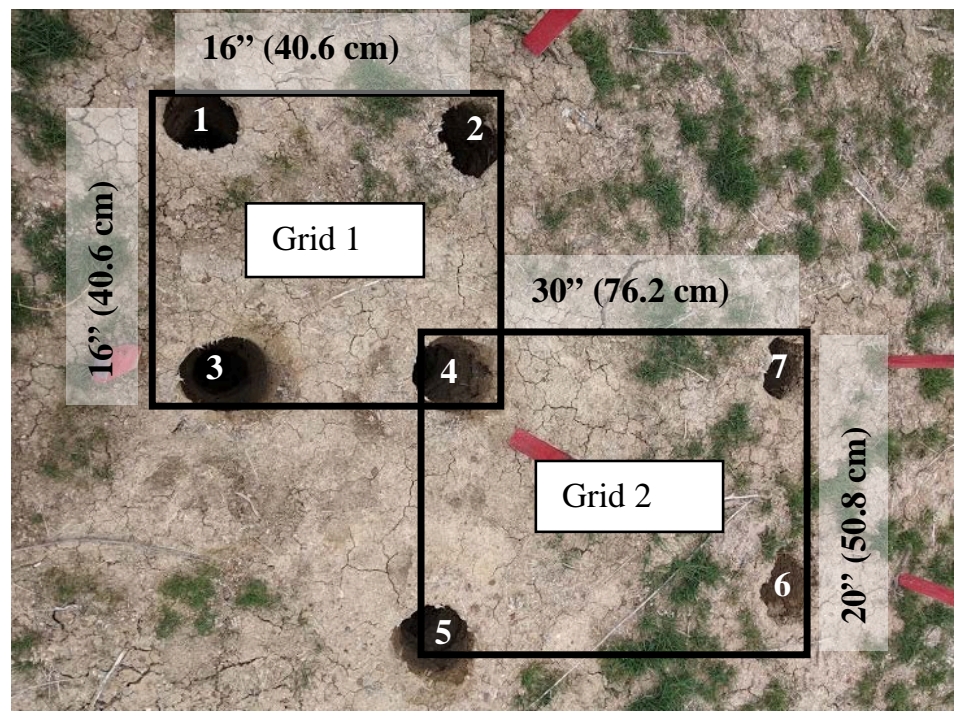

Figure 2 Layout of Injection Points

\section{$\underline{\text { Injection }}$}

The pneumatic packer tube was inserted into the injection points to inject solutions into the ground. A hand pump was used to inflate the rubber lining on the packer tube and seal the holes. This prevented the solutions from easily raising back to the surface. Figure 3 shows the entire equipment setup used for injection of solutions in the field. 


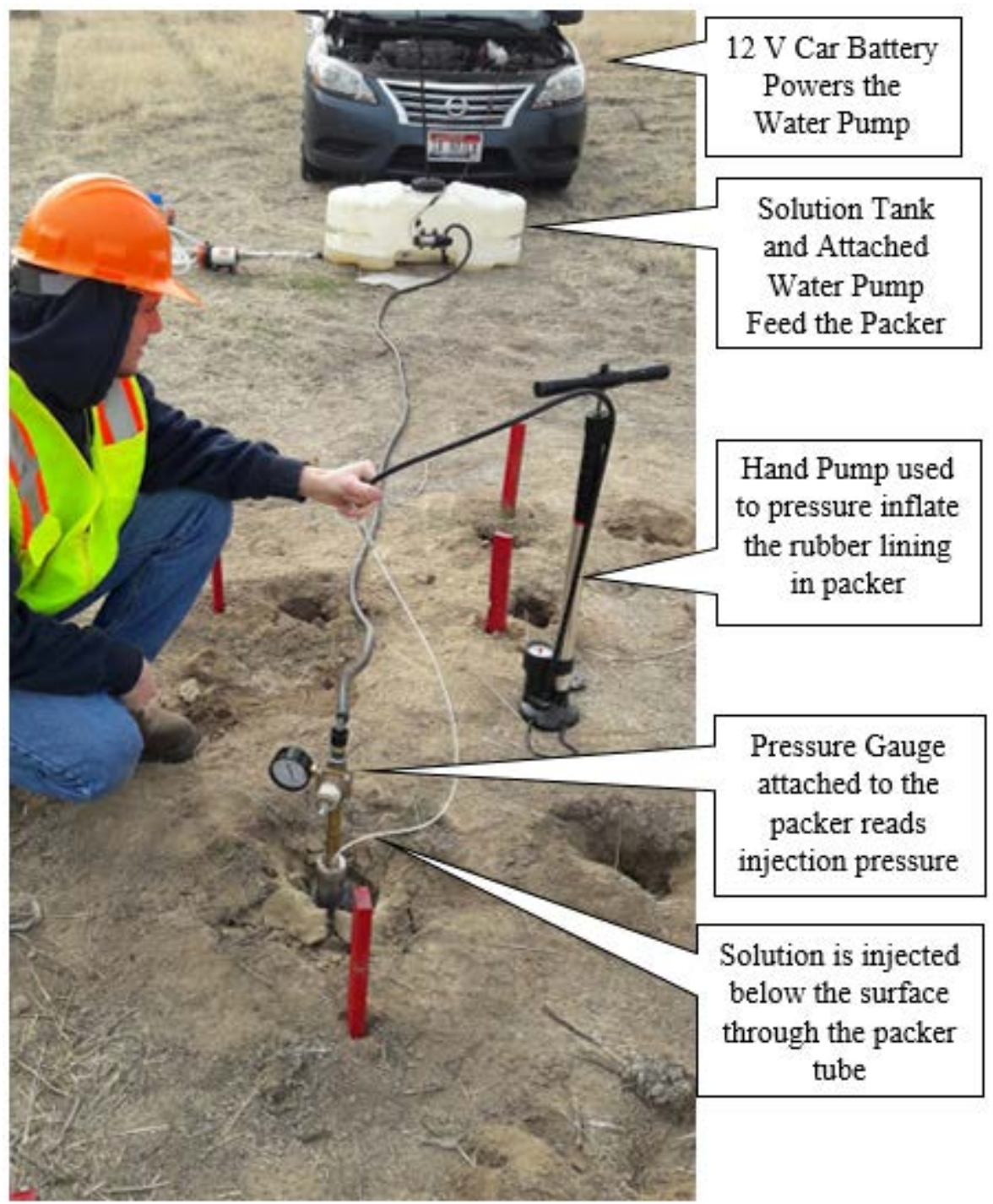

Figure 3 Equipment Setup for Injection of Solution in Field

Table 1 Concentration of Chemicals Used in Enrichment and Cementation Solutions

\begin{tabular}{|c|c|c|c|}
\hline \multirow{2}{*}{ S.N. } & \multirow{2}{*}{ Chemicals } & \multicolumn{2}{|c|}{ Concentration (gm/ltr) } \\
\cline { 3 - 4 } & & Enrichment Solution & Cementation Solution \\
\hline 1 & Urea & 20 & 20 \\
\hline 2 & Sodium Acetate Anhydrous & 8.2 & 4.1 \\
\hline 3 & Solulys & 0.5 & 0.5 \\
\hline 4 & Calcium Chloride & - & 27.74 \\
\hline
\end{tabular}

The injections were done at pressures ranging between $14 \mathrm{psi}(96 \mathrm{kPa})$ to $20 \mathrm{psi}(138 \mathrm{kPa})$. It should be noted here that the pressure gauge did not show a loss of pressure after reaching a peak point, which is a common observation when fracking occurs. This suggests that fracking may not have occurred and the injection was not going through preferential pathways during the operation. Further observations may be needed to confirm this aspect. 
This is an author-produced, peer-reviewed version of this conference proceeding. The final, definitive version of this document can be found online at Geo-Congress 2020, published by the American Society of Civil Engineers. Copyright restrictions may apply. doi: $10.1061 / 9780784482834.013$

Each injection point was injected with 3-6 gallons (11.35 - 22.7 liters) of solution. Injection operation was stopped when the treatment solutions started rising from the sides of the packer lining on to the surface. As the injection process continued, soil surrounding the packer deformed, leaving a gap between the packer lining and the soil through which treatment solutions could escape upwards. The research team was able to inject about 4 gallons (15 liters) of solution per point during each round of injection. The amount of treatment solutions required for each cycle was determined based on the pore volume of the targeted treatment section. The research team targeted to treat approximately $2 \mathrm{ft}$ $(60.96 \mathrm{~cm})$ of soil across each grid. The approximate pore volume of the target area (16" X 16" X 24" or $40.64 \mathrm{~cm} \mathrm{x}$ $40.64 \mathrm{~cm} \times 60.96 \mathrm{~cm}$ ) was determined to be 19 gallons (71.92 liters). To ensure that all pores had access to the treatment solutions 24 gallons (90.84 liters) of the treatment solutions were injected for each round of treatment.

The enrichment and cementation solutions were injected at different time intervals depending on soil $\mathrm{pH}$. The first injection was done with the enrichment solution. The consecutive injection of cementation solution was done after 7 days when $\mathrm{pH}$ of the soil had risen from 8.3 to 9.7 (see Figure 4 below). This is likely due to a rise in population of the urease producing bacteria that facilitate in calcite precipitation. After the injection of enrichment solution, three consecutive injections of cementation solutions were made at an interval of 7 days. A fourth injection of cementation solution was done 14 days after the third cementation. The timeline for all injections made during the study period is: Day 0 - Enrichment, Day 7 - Cementation Round 1, Day 14 - Cementation Round 2, Day 21 - Cementation Round 3 and Day 35 - Cementation Round 4.

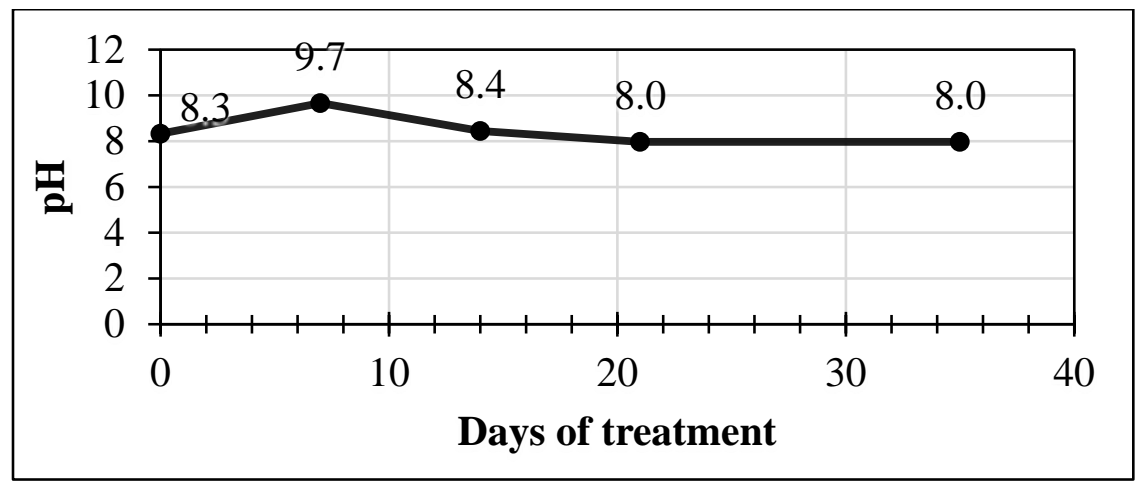

Figure 4 Change in soil $p H$ with time since first injection

\section{Observation and Results}

\section{Lateral Influence of Injection}

During the process of injection, the solution was seen to be flowing into a neighboring injection point through the soil. This observation was made within injection points at a distance of 16 ” $(40.6 \mathrm{~cm})$. This suggests that the solutions could flow laterally up to at least the distance the 16 " $(40.6 \mathrm{~cm})$ when injected at a pressure of $20 \mathrm{psi}(138 \mathrm{kPa})$. The following picture shows the leakage of solution from one injection point to another (Figure 5). 


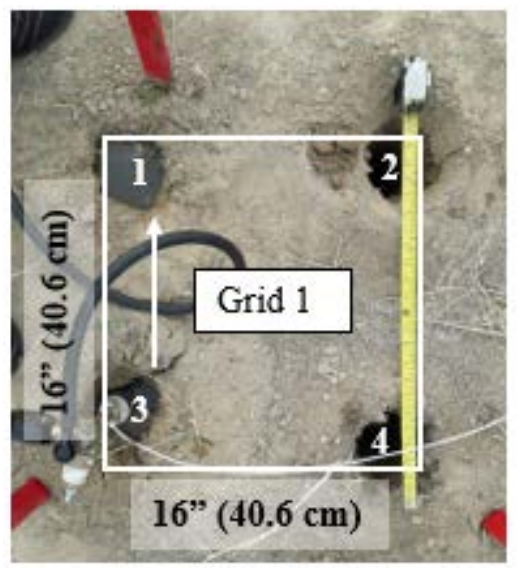

Figure 5 Flow of solution between injection points

The flow of solution into neighboring injection point was seen between points 3 and point 4 during the injection of enrichment solution and first round of cementation solution. However, during the second round of cementation injections, it was observed that the injection was flowing between point 1 and point 3 . The change in flow path could be due to blockage of flow lines with gradual precipitation of calcite in the soil. As calcite precipitation occurs and particles are bonded together, the initial flow path can get restricted. So, a consecutive injection in the same point could result in the solution taking alternate pathways.

\section{Calcite Concentration}

The calcium carbonate content in the soil was detected by mixing the air-dried soil with 1N HCL in an airtight container and measuring the pressure of carbon dioxide gas produced. A calibration of pressure readings with known amounts of calcium carbonate can be used to calculate the calcium carbonate in the soil sample. Soil samples from field showed that there was consistent rise in concentration of calcite at the injection points with every round of cementation injection as seen in Figure 6.

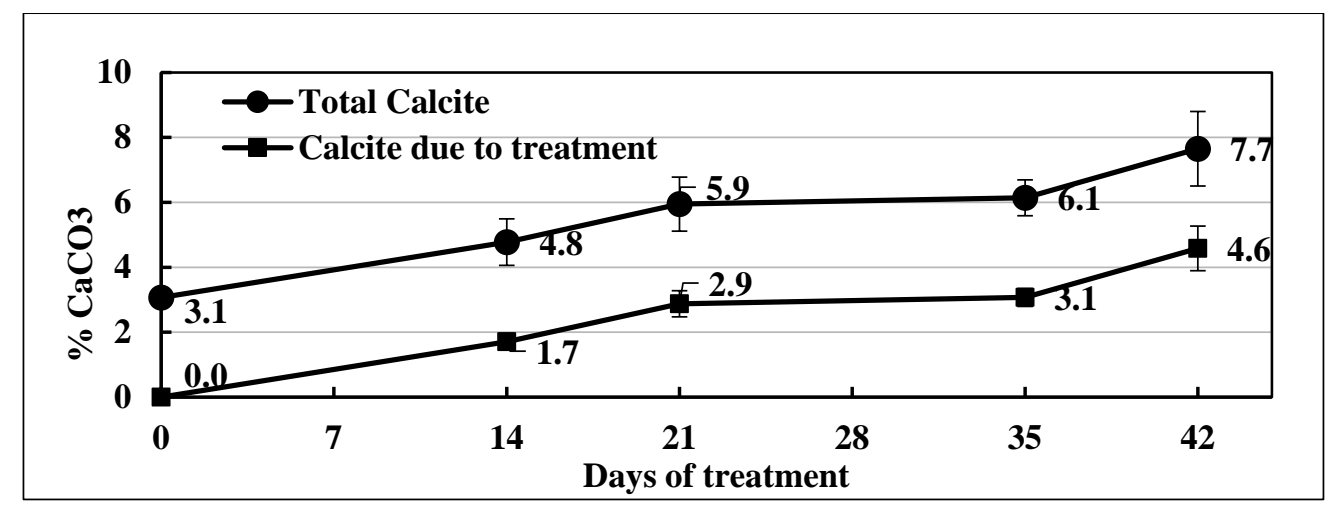

Figure 6 Change in calcite content

\section{Swelling Potential}

The swelling potential of the soil was compared using a free swell index test with kerosene. The free swell index test is an experimental procedure performed to estimate the expansion potential of a given soil (Holtz \& Gibbs, 1956). It is defined as the ratio between the difference in volumes of a soil submerged in distilled water (polar fluid) and kerosene (nonpolar fluid) without any external constraints for 24 hours to the volume of the soil submerged in kerosene after 24 hours. In this test, two representative oven-dried soil samples (passing \# 40 sieve) weighing 10 grams each were poured into two graduated cylinders of $100 \mathrm{ml}$ capacity. One cylinder was filled with distilled water while the other was filled with kerosene up to the $100 \mathrm{ml}$ mark. Entrapped air was removed by minor shaking and stirring with 
This is an author-produced, peer-reviewed version of this conference proceeding. The final, definitive version of this document can be found online at Geo-Congress 2020, published by the American Society of Civil Engineers. Copyright restrictions may apply. doi: $10.1061 / 9780784482834.013$

a glass rod. Soil samples are allowed to attain equilibrium state (without any further change in the volume) for a duration of 24 hours (Sridharan \& Prakash, 2000). The final volume of soil samples in both cylinders are recorded after 24 hours, and the FSI is measured using equation 1.

$$
\text { Free Swell Index }(F S I)(\%)=\frac{\left(V_{d}-V_{k}\right)}{V_{k}} \times 100
$$

Where,

$\mathrm{V}_{\mathrm{d}}=$ Volume of the soil sample from the graduated cylinder containing distilled water.

$\mathrm{V}_{\mathrm{k}}=$ Volume of the soil sample from the graduated cylinder containing Kerosene.

The swelling potential of the soil was compared using a free swell index test with kerosene. Tests with samples collected at injection points showed that the free swell index decreased significantly with each treatment at the injection points (Figure 7).

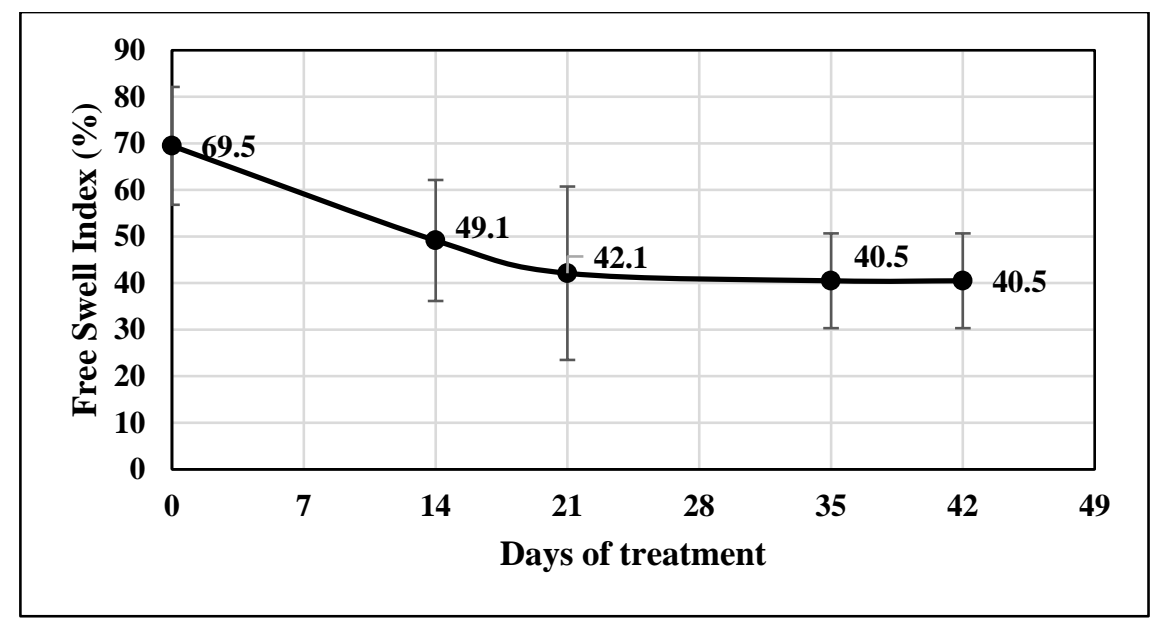

Figure 7 Change in free swell index with treatment injections

\section{Conclusion and Recommendation}

The results of the field test showed that the calcite content increases significantly with each successive injection of cementation solution and reduces swelling potential of the soil. Calcite precipitation increased with treatments (up to $8 \%$ total) and the free swell index dropped from $114 \%$ to $29 \%$. This study shows that microbial induced calcite precipitation can be successfully replicated in the field through successive injections of enrichment and cementation solutions into the soil. The current method of injection and treatment could be applied in existing highways that are built on expansive soils. This could potentially reduce the repair and maintenance costs in the long term.

The treatment methods still need perfection and further research is necessary to optimize the process. The homogeneity of the calcite precipitation and its effects on the volumetric behavior of expansive soils need to be studied in a larger scale to understand the full benefits of MICP. The durability of the treatments and the precipitated calcite also needs to be studied. Instrumentation and on-site measuring devices will be necessary to measure and monitor the physical and chemical changes in the soil. An in-depth study in the possibility of field application could potentially lead to a revolutionary method for stabilizing expansive soils. 
This is an author-produced, peer-reviewed version of this conference proceeding. The final, definitive version of this document can be found online at Geo-Congress 2020, published by the American Society of Civil Engineers. Copyright restrictions may apply. doi: $10.1061 / 9780784482834.013$

\section{References}

Al Qabany, A., \& Soga, K. (2013). Effect of Chemical Treatment Used in MICP on Engineering Properties of Cemented Soils. Geotechnique, 62(4).

Burbank, M. B., Weaver, T. J., Green, T. L., Williams, B. C., \& Crawford, R. L. (2011). Precipitation of Calcite by Indigenous Microorganisms to Strengthen Liquefiable Soils. Geomicrobiology Journal, 28(4), 301-312.

Burbank, M. B., Weaver, T. J., Williams, B. C., \& Crawford, R. L. (2012). Urease Activity of Ureolytic Bacteria Isolated from Six Soils in Which Calcite Was Precipitated by Indigenous Bacteria. Geomicrobiology Journal. doi:https://doi.org/10.1080/01490451.2011.575913

Burbank, M., Weaver, T., Lewis, R., Williams, T., Williams, B., \& Crawford, R. (2013). Geotechnical Tests of Sands Following Bioinduced Calcite Precipitation Catalyzed by Indigenous Bacteria. Journal of Geotechnical and Geoenvironmental Engineering.

Clough, G., Iwabuchi, J., Rad, N., \& Kuppusami, T. (1989). Influence of Cementation on Liquifaction of Sands. Journal of Geotechnical Engineering, 115(8), 1102-1117.

DeJong, J. T., Fritzges, M. B., \& Nusslein, K. (2006). Microbially Induced Cementation to Control Sand Response to Undrained Shear. Journal of Geotechnical and Geoenvironmental Engineering, 132(11), 1381-1392.

Gomez, M. G., Graddy, C. M., DeJong, J. T., Nelson, D. C., \& Tsesarsky, M. (2018). Stimulation of Native Microorganisms for Biocementation in Samples Recovered from Field Scale Treatment Depths. Journal of Geotechnical and Geoenvironmental Engineering. doi:https://doi.org/10.1061/(ASCE)GT.19435606.0001804

Holtz, W. G., \& Gibbs, H. J. (1956). Triaxial Shear Tests on Pervious Gravelly Soils BT - American Society of Civil Engineers - Proceedings. American Society of Civil Engineers - Proceedings - Journal of the Soil Mechanics and Foundations Division.

Jones Jr, D. E., \& Holtz, W. G. (1973, August). Expansive Soils - The Hidden Disaster. Civil Engineering, 49-51.

Martinez, B., DeJong, J., Ginn, T., Montoya, B., Barkouki, T., C., H., . . Major, D. (2013). Experimental Optimization of Microbial-Induced Carbonate Precipitation for Soil Improvement. Journal of Geotechnical and Geoenvironmental Engineering, 139(4), 587-598.

Mujah, D., Shahin, M. A., \& Cheng, L. (2017). State-of-the-Art Review of Biocementation by Microbially Induced Calcite Precipitation (MICP) for Soil Stabilization. Geomicrobiology Journal, 524-537. doi:10.1080/01490451.2016.1225866

Pengelly, A., Boehm, D., \& Rector, E. (1997). Experience with In-Situ Modification of Collapsible and Expansive Soils. Unsaturated Soil Engineering Practice (pp. 88-112). Logan, UT, USA: ASCE Geotechnical Special Publication.

Phanikumar, B. R., Sharma, R., Rao, S., \& Madhav, M. (2004). Granular Pile-Anchor Foundation (GPAF) System for Improving the Engineering Behavior of Expansive Clay Beds. Geotechnical Testing Journal, 27(3), 279-287.

Puppala, A., Bhadriraju, V., \& Probaha, A. (2005). Quality Assurance Practices and Protocols for in-Situ Testing of Deep Mixed Columns.

Rao, A. S., Phanikumar, B., Dayakar, B. R., \& Suresh, K. (2004). Pullout Behavior of Granular Pile-Anchors in Expansive Clay Beds in Situ. Geotechnical Testing Journal, 133(5), 531-538.

Sridharan, A., \& Prakash, K. (2000). Classification Procedures for Expansive Soils. Proceedings of the Institution of Civil Engineers - Geotechnical Engineering.

Stocks-Fisher, S., Galinat, J. K., \& Bang, S. S. (1999). Soil Biol Biochem. 31, 1563.

Stotzky, G. (n.d.). Soil as an Environment for Microbial Life. In J. D. Van Elsas, J. T. Trevors, \& E. Wellington, Modern Soil Microbiology (pp. 1-19). New York: Marcel Dekker In. .

Torsvik, V. J., Goksoyr, \& Daae, F. (1990). High Diversity in DNA of Soil Bacteria. Applied and Environmental Microbiology, 27(3), 782-787.

Tsesarsky, M., Gat, D., \& Ronen, Z. (2016). Biological Aspects of Microbial-Induced Calcite Precipitation. Environmental Geotechnics. doi:https://doi.org/10.1680/jenge.15.00070

UNEP. (2010). Greening Cement Production Has a Big Role to Play in Reducing Greenhouse Gas Emmissions. UNEP.

van Paasen, L. A. (2009). Biogrout, Ground Improvement by Microbially Induced Carbonate Precipitation. the Netherlands: Department of Biotechnology, Delft University of Technology.

van Paassen, L. A. (2011). Bio-Mediated Ground Improvement: From Labotatory Experiment to Pilot Applications. 
This is an author-produced, peer-reviewed version of this conference proceeding. The final, definitive version of this document can be found online at Geo-Congress 2020, published by the American Society of Civil Engineers. Copyright restrictions may apply. doi: $10.1061 / 9780784482834.013$

van Paassen, L. A., Ghose, R., van der Linden, T. J., van der Star, W. R., \& van Loosdrecht, M. C. (2010). Quantifying Biomediated Ground Improvement by Ureolysis: Large-Scale Biogrout Experiment. Journal of Geotechnical and Geoenvironmental Engineering, 136(12), 1721-1728.

van Paassen, L. A., Whiffin, V. S., \& Harkes, M. P. (2007). Microbial Carbonate Precipitation as a Soil Improvement Technique. Geomicrobiology Journal, 24(5), 417-423.

van Veen, J. A., van Overbeek, L. S., \& van Elsas, J. D. (1997). Fate and Activity of Microorganisms Introduced into Soil. Microbiology and Molecular Biology Reviews, 61(2), 121-135.

Whiffin, V. S., van Paassen, L. A., \& Harkes, M. P. (2007). Microbial Carbonate Precipitation as a Soil Improvement Technique. Geomicrobiology Journal. doi:https://doi.org/10.1080/01490450701436505 